\title{
PENGARUH KONSENTRASI ETANOL DAN LAMA DERAAN PADA VIABILITAS BENIH BUNCIS (Phaseolus vulgaris L.)
}

\author{
Madya Dwi Aji Handayani, Eko Pramono \& M. Syamsoel Hadi \\ Jurusan Agroteknologi, Fakultas Pertanian Universitas Lampung \\ Jl. Prof. Soemantri Brodjonegoro, No. 1, Bandar Lampung 35145 \\ E-mail:madya_dya@yahoo.com
}

\begin{abstract}
ABSTRAK
Perlakuan penderaan secara kimiawi dapat dilakukan dengan menggunakan etanol. Penelitian ini bertujuan untuk mengetahui pengaruh konsentrasi etanol dan lama deraan pada viabilitas benih buncis (Phaseolus vulgaris L.). Penelitian ini menggunakan rancangan perlakuan faktorial $(3 \times 4)$ dalam rancangan kelompok teracak lengkap (RKTL) dengan tiga ulangan, faktor pertama, yaitu konsentrasi etanol $(0 \%, 3 \%, 6 \%$, dan $9 \%)$ dan faktor kedua adalah lama waktu deraan $(6,12$, dan 18 jam). Homogenitas ragam diuji dengan Uji Bartlett dan kemenambahan model diuji dengan Uji Tukey dan untuk melihat perbedaan antarnilai tengah perlakuan dilakukan Uji Beda Nyata Terkecil (BNT) pada $\alpha=0,05$. Hasil penelitian menunjukkan bahwa: 1) konsentrasi etanol 9\% mampu menurunkan viabilitas benih buncis yang ditunjukkan oleh menurunnya kecambah normal total, bobot kering kecambah normal, dan meningkatkan benih mati, 2) lama deraan 18 jam dapat menurunkan viabilitas ditunjukkan oleh variabel kecambah normal kuat, 3) pengaruh interaksi konsentrasi etanol dan lama deraan nyata ditunjukkan oleh kecepatan perkecambahan, kecambah abnormal, dan panjang akar primer. Kombinasi antara konsentrasi etanol $9 \%$ dan lama deraan 18 jam menghasilkan nilai viabilitas yang masih bervariasi.
\end{abstract}

Kata kunci: benih, buncis, etanol, lama deraan, viabilitas.

\section{PENDAHULUAN}

Pertanaman kacang buncis (Phaseolus vulgaris L.) tergolong paling luas diantara empat spesies phaseolus yang diusahakan dan semuanya berasal dari Amerika. Buncis merupakan sayuran polong sebagai sumber protein nabati yang murah dan mudah dikembangkan. Berdasarkan data statistik tahun 2006 hingga 2011, terjadi penurunan produksi buncis antara tahun 2010 dan tahun 2011 (1,835 ton tahun $\left.{ }^{-1}\right)$. Penurunan produksi benih buncis dikarenakan sedikitnya industri benih buncis lokal yang ada, sehingga produksi benih buncis dinilai prospek untuk dikembangkan di Indonesia. Teknologi penyimpanan memiliki andil dalam produksi benih. Benih yang mengalami masa simpan akan mengalami kemunduran viabilitasnya. Menurut Kartasapoetra (1992), dalam mengetahui kemunduran dari suatu benih, maka diperlukan uji tertentu yang bertujuan untuk mengetahui mutu dan kualitas dari suatu jenis atau kelompok benih. Sehingga dapat membantu dalam menentukan mutu fisik dan fisiologik suatu jenis atau kelompok benih. Penderaan kimiawi merupakan salah satu metode pengusangan cepat benih secara buatan. Uji pengusangan dipercepat tergolong dalam metode uji vigor benih dengan lingkungan suboptimum sebelum benih dikecambahkan. Pengusangan benih dengan alkohol dapat digunakan untuk menguji kemunduran benih akibat keracunan yang ditimbulkan oleh alkohol (Mugnisjah dkk., 1994). Kemunduran benih yang diterapkan etil alkohol dipengaruhi oleh lama perlakuan dan jumlah etil alkohol yang terdapat dalam benih tersebut. Penderaan benih oleh uap etil alkohol mengakibatkan perubahan pada viabilitas benih (Pian, 1981).

Penelitian sebelumnya mengenai pendugaan daya simpan benih secara alami diketahui bahwa benih yang disimpan semakin lama akan semakin mundur viabilitasnya. Semakin lama benih melalui periode simpannya, maka kandungan etanol dalam benih akan semakin meningkat dan viabilitasnya akan semakin rendah (Pramono, 2009). Menurut Pian (1981), uap etanol dapat diserap oleh benih dan pada konsentrasi tertentu akan berpengaruh buruk terhadap tampilan vigor benih. Uap etanol diketahui dapat menyebabkan perubahan sifat molekul makro yang berpengaruh terhadap aktivitas enzim, membran sel, mitokondria serta organel-organel sel lainnya yang berperan dalam metabolisme perkecambahan.

Berdasarkan landasan teori dan kerangka pemikiran yang telah disusun, dapat dirumuskan hipotesis sebagai berikut: konsentrasi etanol yang berbeda yang diderakan pada benih buncis menyebabkan perbedaan viabilitas benih buncis. Lama waktu deraan dengan konsentrasi etanol yang berbeda -beda akan 
menyebabkan perbedaan pada viabilitas benih buncis. Viabilitas benih yang terjadi akibat deraan denga larutan etanol juga ditentukan oleh lamanya benih didera dengan larutan etanol tersebut.

\section{BAHAN DAN METODE}

Bahan-bahan yang digunakan dalam penelitian ini adalah benih buncis varietas "Dwell" yang dipanen pada bulan Juni 2012 dari pertanaman di Desa Jatimulyo, Kecamatan Jati Agung, Lampung Selatan. Benih Sumber untuk pertanaman tersebut merupakan benih yang dikeluarkan oleh Balai Penelitian Tanaman Sayuran (BALITSA), Lembang, Provinsi Jawa Barat; larutan etanol dengan konsentrasi 0\%, 3\%, 6\%, 9\%; dan air. Alat-alat yang digunakan adalah gelas ukur; kertas merang berukuran $20 \mathrm{~cm} \times 30 \mathrm{~cm}$; plastik berukuran $20 \mathrm{~cm}$ x $30 \mathrm{~cm}$; karet gelang; Alat Pengecambah Benih (APB) tipe IPB 73-2A/B; oven; timbangan elektrik; millimeter block; kamera; dan alat tulis.

Pembuatan konsentrasi etanol 3\% dilakukan dengan cara melarutkan larutan etanol $70 \%$ sebanyak 42,56 $\mathrm{ml}$ ke dalam 957,44 $\mathrm{ml}$ air.

Rumus: $\quad \mathrm{M}_{1} \mathrm{~V}_{1}=\mathrm{M}_{2} \mathrm{~V}_{2}$

dengan $\mathrm{M}_{1}=$ konsentrasi etanol yang digunakan, $\mathrm{V}_{1}=$ volume air yang dicari, $\mathrm{M}_{2}=$ konsentrasi etanol yang dicari, $\mathrm{V}_{2}=$ volume air yang digunakan, dan $\mathrm{V}_{1}-\mathrm{V}_{2}=$ volume air dikurangi konsentrasi etanol yang didapat.

Untuk menguji kesahihan data, maka disusun perlakuan secara faktorial $4 \times 3$ dalam rancangan kelompok teracak lengkap (RKTL) dengan tiga kali ulangan. Konsentrasi etanol $(0 \%, 3 \%, 6 \%$, dan 9\%) merupakan faktor pertama dalam rancangan ini dan lama deraan (6 jam, 12 jam, dan 18 jam) sebagai faktor kedua. Homogenitas ragam diuji dengan Uji Bartlett dan kemenambahan model diuji dengan Uji Tukey dan untuk melihat perbedaan antar nilai tengah perlakuan dilakukan Uji Beda Nyata Terkecil (BNT) pada $\alpha=0,05$.

Untuk menguji kesahihan kerangka pemikiran dan hipotesis yang telah dikemukakan, dilakukan pengamatan terhadap kecepatan berkecambah (UKP) dan keserempakan perkecambahan (UKsP). Pengamatan kecambah untuk UKP dilakukan setiap hari mulai dari hari ke-3 hingga hari ke-5. Pengamatan kecambah untuk UKsP dilakukan pada hari ke-4. berikut:
1.Uji Kecepatan Perkecambahan (UKP)

a) Kecepatan perkecambahan, dimulai pada hari ketiga hingga hari kelima dengan menghitung persentase kecambah normal yang tumbuh per hari. Kecepatan perkecambahan dihitung dnegan rumus $\mathrm{KP}=\Sigma$ $(\% \mathrm{KN}) / \mathrm{T}_{i}$, dengan $\% \mathrm{KN}=$ persentase kecambah normal pengamatan hari ke-i $\mathrm{T}_{\mathrm{i}}=$ hari pengamatan sampai dengan hari ke-i (5).

b) Kecambah normal total, dilakukan dengan cara menghitung jumlah kecambah normal dari UKP.

c) Benih mati, diamati dengan cara menghitung jumlah benih yang mati dari UKP.

d) Kecambah abnormal, dilakukan dengan menghitung kecambah abnormal, yaitu memiliki kekurangan pada bagian-bagian meliputi: tidak sempurnanya panjang akar primer dan/ atau hipokotil tidak tumbuh normal dari UKP.

2. Uji Keserempakan Perkecambahan (UKsP)

a) Kecambah normal kuat, dilakukan dengan menghitung jumlah kecambah normal kuat, yaitu kecambah dengan akar primer dan plumula yang tumbuh sempurna (tanpa cacat) dari UKsP.

b) Kecambah normal lemah, dilakukan dengan menghitung jumlah kecambah normal lemah, yaitu kecambah dengan akar primer dan plumula yang tumbuh dengan tidak sempurna dari UKsP.

c) Panjang hipokotil dan panjang akar primer, diamati pengamatannya dengan mengukur panjang tajuk pada kecambah normal yang berasal dari UKsP. Panjang akar primer diukur dari titik tumbuh (pangkal batang) hingga bagian ujung akar primer.

d) Bobot kering kecambah normal, dilakukan dengan menggunakan kecambah normal hasil UKsP. Kecambah normal setelah dipisahkan dari kotiledonnya, kemudian dikeringkan dengan oven pada suhu $70^{\circ} \mathrm{C}$ selama $3 \times 24$ jam. Selanjutnya benih kering ditimbang menggunakan timbangan elektrik.

\section{HASIL DAN PEMBAHASAN}

Hasil penelitian menunjukkan bahwa konsentrasi etanol berpengaruh nyata terhadap kecambah normal total, benih mati, kecambah normal kuat, dan bobot kering kecambah normal pada viabiltas benih buncis. Namun, pengaruh lama deraan hanya nyata pada kecambah normal total, benih mati, dan kecambah normal kuat pada viabilitas benih buncis. Pengaruh interaksi antara konsentrasi etanol dan lama deraan nyata pada 
kecepatan perkecambahan, kecambahan abnormal, dan panjang akar primer pada viabilitas benih buncis. Tidak terdapat pengaruh interaksi yang nyata pada kecambah normal total, benih mati, panjang hipokotil, kecambah normal kuat, kecambah normal lemah, dan bobot kering kecambah normal pada viabilitas benih buncis.

Hasil penelitian (Tabel 1) menunjukkan bahwa kecambah normal total menurun persentasenya saat didera dengan etanol konsentrasi 9\%, yaitu sebesar $6,45 \%$ dibandingkan kecambah normal total yang didera dengan etanol konsentrasi $0 \%$. Konsentrasi etanol yang meningkat tidak menurunkan persentase benih mati pada viabilitas benih buncis. Konsentrasi etanol 0\%,3\%, dan $6 \%$ tidak menghasilkan perbedaan yang nyata terhadap persen benih mati pada viabilitas benih buncis dan kecambah normal kuat, sedangkan konsentrasi etanol 9\% menghasilkan benih mati lebih banyak $(0,74 \%)$ dan kecambah normal kuat lebih tinggi $(7,33 \%)$ dibandingkan tanpa etanol. Pada bobot kering kecambah normal, perbedaan mulai terjadi saat benih didera dengan etanol konsentrasi 3\% hingga konsentrasi 9\%.

Hasil penelitian (Tabel 2) menunjukkan bahwa lama deraan 18 jam persentase kecambah normal total kembali meningkat dan persentase benih mati menurun. Pada lama waktu deraan 6 jam dan 18 jam tidak menurunkan persentase kecambah normal total. Lama deraan 6 jam dan 12 jam, tidak berbeda nyata dalam menurunkan kecambah normal kuat. Pada lama deraan 18 jam sudah mampu menurunkan kecambah normal kuat sebesar 7,50\% dibandingkan kontrol.

Hasil penelitian (Tabel 3) menunjukkan bahwa pada konsentrasi etanol 9\% menunjukkan adanya perbedaan antara penderaan 12 jam dan 18 jam dalam memperlambat perkecambahan, masing-masing (12,43\% per hari) dan (11,94\% per hari) dibandingkan penderaan 6 jam yang laju perkecambahannya 8,89\% per hari. Pada deraan 12 jam, konsentrasi etanol 3\% hingga $9 \%$ berbeda nyata memperlambat perkecambahan dibandingkan tanpa etanol.

Hasil penelitian (Tabel 4) menunjukkan bahwa pada deraan 6 jam dan 18 jam konsentrasi etanol 9\% nyata dalam meningkatkan kecambah abnormal dibandingkan konsentrasi etanol 3\% dan 6\%, namun pada deraan 12 jam tidak menunjukkan perbedaan. Pada konsentrasi etanol $9 \%$ peningkatan kecambah abnormal pada deraan 6 jam $(0,50 \%)$ dan 18 jam $(0,38 \%)$ lebih tinggi dibandingkan tanpa etanol, kecuali pada deraan 12 jam tidak menunjukkan adanya perbedaan.

Hasil penelitian (Tabel 5) menunjukkan bahwa deraan 6 jam dan 18 jam tidak berpengaruh nyata dalam menurunkan panjang akar primer, kecuali pada etanol $9 \%$ pada deraan 12 jam berpengaruh nyata menurunkan

Tabel 1. Pengaruh konsentrasi etanol terhadap viabilitas benih buncis

\begin{tabular}{ccccc}
\hline $\begin{array}{c}\text { Konsentrasi } \\
\text { etanol (\%) }\end{array}$ & $\begin{array}{c}\text { Kecambah normal } \\
\text { total }(\%)\end{array}$ & Benih mati (\%) & $\begin{array}{c}\text { Kecambah normat } \\
\text { kuat }(\%)\end{array}$ & $\begin{array}{c}\text { Bobot kering kecambah } \\
\text { normal }(\mathrm{mg})\end{array}$ \\
\hline 0 & $90,89 \mathrm{a}$ & $2,39 \mathrm{~b}$ & $62,44 \mathrm{~b}$ & $101,11 \mathrm{a}$ \\
3 & $93,33 \mathrm{a}$ & $2,66 \mathrm{~b}$ & $59,11 \mathrm{~b}$ & $86,97 \mathrm{~b}$ \\
6 & $91,56 \mathrm{a}$ & $2,76 \mathrm{ab}$ & $60,89 \mathrm{~b}$ & $85,91 \mathrm{~b}$ \\
9 & $84,44 \mathrm{~b}$ & $3,13 \mathrm{a}$ & $69,11 \mathrm{a}$ & $81,64 \mathrm{~b}$ \\
\hline BNT & 4,49 & 0,38 & 6,69 & 12,9 \\
\hline
\end{tabular}

Keterangan: Nilai tengah sekolom yang diikuti huruf yang sama tidak berbeda berdasarkan berdasarkan uji BNT $\alpha=0,05$.

Tabel 2. Pengaruh lama penderaan terhadap viabilitas benih buncis

\begin{tabular}{cccc}
\hline $\begin{array}{c}\text { Lama penderaan } \\
(\mathrm{Jam})\end{array}$ & $\begin{array}{c}\text { Kecambah normal total } \\
(\%)\end{array}$ & $\begin{array}{c}\text { Benih mati } \\
(\%)\end{array}$ & $\begin{array}{c}\text { Kecambah normal kuat } \\
(\%)\end{array}$ \\
\hline 6 & $90,67 \mathrm{ab}$ & $2,94 \mathrm{a}$ & $67,17 \mathrm{a}$ \\
12 & $87,17 \mathrm{~b}$ & $2,80 \mathrm{ab}$ & $61,83 \mathrm{a}$ \\
18 & $92,33 \mathrm{a}$ & $2,48 \mathrm{~b}$ & $59,67 \mathrm{~b}$ \\
\hline BNT $=$ & 3,88 & 0,33 & 5,79 \\
\hline
\end{tabular}

Keterangan: Nilai tengah sekolom yang diikuti huruf yang sama tidak berbeda berdasarkan berdasarkan uji BNT $\alpha=0,05$. 
Tabel 3. Pengaruh interaksi konsentrasi etanol dan lama penderaan terhadap kecepatan perkecambahan pada viabilitas benih buncis

\begin{tabular}{cccc}
\hline \multirow{3}{*}{$\begin{array}{c}\text { Konsentrasi } \\
\text { etanol (\%) }\end{array}$} & \multicolumn{3}{c}{ Kecepatan perkecambahan (\% per hari) } \\
\cline { 2 - 4 } & 6 jam & Lama penderaan \\
\cline { 2 - 4 } & $10,92 \mathrm{ab}$ & $9,22 \mathrm{a}$ & $18 \mathrm{jam}$ \\
\hline & $\mathrm{AB}$ & $\mathrm{A}$ & $12,01 \mathrm{~b}$ \\
& $11,62 \mathrm{~b}$ & $12,01 \mathrm{~b}$ & $\mathrm{~B}$ \\
3 & $\mathrm{AB}$ & $\mathrm{B}$ & $9,67 \mathrm{a}$ \\
& $10,27 \mathrm{ab}$ & $11,94 \mathrm{~b}$ & $\mathrm{~A}$ \\
6 & $\mathrm{AB}$ & $\mathrm{B}$ & $8,83 \mathrm{ab}$ \\
& $8,93 \mathrm{a}$ & $12,43 \mathrm{~b}$ & $\mathrm{~A}$ \\
9 & $\mathrm{~A}$ & $\mathrm{~B}$ & $11,94 \mathrm{~b}$ \\
BNT & & 2,03 & $\mathrm{~B}$ \\
\hline
\end{tabular}

Keterangan: Nilai tengah yang diikuti oleh huruf kecil yang sama (sekolom) atau huruf kapital yang sama (sebaris) menunjukkan tidak berbeda nyata berdasarkan uji BNT $\alpha=0,05$.

Tabel 4. Pengaruh interaksi konsentrasi etanol dan lama penderaan terhadap kecambah abnormal pada viabilitas benih buncis

\begin{tabular}{cccc}
\hline & \multicolumn{3}{c}{ Jumlah kecambah normal (\%) } \\
\cline { 2 - 4 } $\begin{array}{c}\text { Konsentrasi } \\
\text { etanol }(\%)\end{array}$ & \multicolumn{3}{c}{ Lama penderaan } \\
\cline { 2 - 4 } & 6 jam & 12 jam & 18 jam \\
\cline { 2 - 4 } & $2,55 \mathrm{a}$ & $2,93 \mathrm{a}$ & $2,50 \mathrm{ab}$ \\
0 & $\mathrm{~A}$ & $\mathrm{~B}$ & $\mathrm{~A}$ \\
& $2,55 \mathrm{a}$ & $2,67 \mathrm{a}$ & $2,71 \mathrm{ab}$ \\
& $\mathrm{A}$ & $\mathrm{A}$ & $\mathrm{A}$ \\
6 & $2,76 \mathrm{ab}$ & $2,93 \mathrm{a}$ & $2,37 \mathrm{a}$ \\
& $\mathrm{B}$ & $\mathrm{B}$ & $\mathrm{A}$ \\
9 & $3,07 \mathrm{~b}$ & $2,61 \mathrm{a}$ & $2,88 \mathrm{~b}$ \\
$\mathrm{BNT}$ & $\mathrm{B}$ & $\mathrm{A}$ & $\mathrm{Ab}$ \\
\hline
\end{tabular}

Keterangan: Nilai tengah yang diikuti oleh huruf kecil yang sama (sekolom) atau huruf kapital yang sama (sebaris) menunjukkan tidak berbeda nyata berdasarkan uji BNT $\alpha=0,05$.

panjang akar primer $(3,07 \mathrm{~cm})$ dibandingkan tanpa etanol, sedangkan deraan 18 jam menghasilkan panjang akar primer yang terpanjang.

Berdasarkan penelitian yang telah dilakukan menunjukkan bahwa pengaruh konsentrasi etanol terhadap menurunnya viabilitas benih secara tidak konsisten yang ditunjukkan oleh menurunnya persentase kecambah normal total, benih mati, bobot kering kecambah normal, dan kecambah normal kuat. Pada kecambah normal total, konsentrasi etanol 9\% nyata menurunkan persentase kecambah normal total, yaitu sebesar $6,45 \%$ dibandingkan tanpa etanol, sedangkan konsentrasi etanol 0\%, 3\%, dan 6\% menghasilkan persentase yang sama. Berdasarkan hal tersebut diketahui bahwa pada kecambah normal total, benih mulai mengalami kemunduran saat didera dengan konsentrasi etanol 9\%. Hal ini dikarenakan benih berinteraksi terhadap deraan etanol konsentrasi $9 \%$. Benih sudah tidak mampu mentolerir cairan etanol dengan kepekatan 9\% yang masuk ke dalam benih sehingga terjadi penurunan kecambah normal total dan meningkatnya benih mati.

Konsentrasi etanol 9\% mampu menurunkan viabilitas benih buncis ditunjukkan oleh variabel 
Tabel 5. Pengaruh interaksi konsentrasi etanol dan lama penderaan terhadap panjang akar primer pada viabilitas benih buncis

\begin{tabular}{cccc}
\hline \multirow{2}{*}{$\begin{array}{c}\text { Konsentrasi } \\
\text { etanol }(\%)\end{array}$} & \multicolumn{3}{c}{ Panjang akar primer $(\mathrm{cm})$} \\
\cline { 2 - 4 } & 6 jam & Lama penderaan \\
\cline { 2 - 4 } & $7,38 \mathrm{a}$ & 12 jam & $18 \mathrm{jam}$ \\
\hline & $\mathrm{B}$ & $9,28 \mathrm{a}$ & $9,50 \mathrm{a}$ \\
& $8,51 \mathrm{a}$ & $\mathrm{A}$ & $\mathrm{A}$ \\
3 & $\mathrm{~A}$ & $8,61 \mathrm{a}$ & $9,13 \mathrm{a}$ \\
& $8,45 \mathrm{a}$ & $\mathrm{A}$ & $\mathrm{A}$ \\
6 & $\mathrm{~A}$ & $9,23 \mathrm{a}$ & $9,09 \mathrm{a}$ \\
& $8,21 \mathrm{~A}$ & $\mathrm{~A}$ & $\mathrm{~A}$ \\
9 & $\mathrm{~B}$ & $6,21 \mathrm{~b}$ & $9,84 \mathrm{a}$ \\
BNT & & $\mathrm{C}$ & $\mathrm{A}$ \\
\hline
\end{tabular}

Keterangan: Nilai tengah yang diikuti oleh huruf kecil yang sama (sekolom) atau huruf kapital yang sama (sebaris) menunjukkan tidak berbeda nyata berdasarkan uji BNT $\alpha=0,05$.

kecambah normal total dan persentase benih mati lebih banyak $(0,74 \%)$ dibandingkan tanpa etanol. Pada konsentrasi etanol $9 \%$ kecambah meningkat $(7,33 \%)$ dibandingkan dengan tanpa etanol. Penurunan bobot kering kecambah normal setelah didera dengan konsentrasi etanol 3\% menunjukkan perbedaan sebesar $14,14 \%$ dibandingkan dengan tanpa etanol. Hal ini menunjukkan bahwa meskipun viabilitas benih pada konsentrasi 9\% sudah menurun, namun kekuatan tumbuh benih yang didasarkan pada kecambah normal kuat masih tinggi.

Lama deraan memegang andil dalam menurunkan kualitas benih, yaitu menurunkan viabilitas benih buncis. Pada lama deraan 18 jam sudah mampu menurunkan kecambah normal kuat sebesar 7,50\% dibandingkan kontrol. Hal ini menunjukkan bahwa lama deraan 18 jam memberikan pengaruh yang nyata dalam menurunkan persentase kecambah normal kuat pada viabilitas benih buncis.

Interaksi antara konsentrasi etanol 9\% dan lama deraan 18 jam nyata menurunkan viabilitas benih buncis ditunjukkan oleh variabel kecepatan perkecambahan dan kecambah abnormal, sedangkan panjang akar primer tidak menurun. Pada konsentrasi etanol 9\% dan deraan 18 jam nyata menghambat perkecambahan $(11,94 \%$ per hari) dibandingkan deraan 6 jam $(8,89 \%$ per hari) dan meningkatkan kecambah abnormal $(0,38 \%)$ dibandingkan tanpa etanol, namun pada panjang akar primer memiliki rata-rata nilai yang sama dengan perlakuan tanpa etanol. Hal ini menunjukkan bahwa kombinasi antara konsentrasi etanol 9\% dan deraan 18 jam menunjukkan nilai viabilitas yang masih bervariasi berdasarkan variabel kecambah abnormal pada deraan 12 jam masih menghasilkan nilai yang sama dan panjang akar primer yang didera selama 12 jam dengan konsentrasi etanol 9\% masih menghasilkan panjang yang rata-rata sama dengan tanpa etanol.

Benih yang masih vigor dapat mengatur dirinya untuk tidak menyerap etanol tanpa terkendali. Penelitian yang dilakukan oleh Murniati dalam Sadjad (1993), mengungkapkan bahwa benih tidak mengalami kemunduran setelah didera oleh etanol hingga lama 50 PTM. Hal tersebut membuktikan bahwa perlakuan penderaan bersifat kondisional. Berdasarkan penelitian Pian (1981), dibuktikan bahwa benar perlakuan etanol merusak dinding sel benih jagung. Kerusakan tersebut akan mengakibatkan rembesan lebih banyak keluar dari dalam sel. Angelo dan Robert (1983) mengemukakan, bahwa protein memegang peranan penting dalam proses perkecambahan benih baik sebagai protein struktural maupun protein fungsional. Denaturasi protein struktural mengakibatkan kebocoran hasil metabolisme dalam jumlah yang besar sehingga memundurkan sel benih. Agustin (2010) menemukan bahwa penderaan etanol konsentrasi $9 \%$ dan lama deraan 12 jam sudah dapat membedakan tingkat vigor benih kedelai. Hasil penelitian Zanzibar (2007), ditemukan bahwa uap etanol berpengaruh buruk terhadap penurunan kualitas fisiologi pada benih mindi dan merbau, namun tidak ada perbedaan pengaruh terhadap kualitas fisiologi benih akor. Penelitian yang dilakukan oleh Kazumitsu dan Tadashi (1996), perlakuan etanol sebagai pengusangan kimiawi tidak berpengaruh nyata pada pertumbuhan benih padi 'Indica' dalam kondisi anaerob. Buckley dan 
Huang (2011) mengemukakan penelitiannya mengenai konsentrasi etanol pada vigor benih canola, keduanya menemukan bahwa vigor benih canola tidak menurun pada konsentrasi etanol dibawah 20 hingga lebih dari $500 \mu 1 \mathrm{l}^{-1}$ dari standar perkecambahan benih diantara 80-100\%. Penelitian yang dilakukan oleh Tatipata dkk. (2004) menunjukkan bahwa kemunduran viabilitas benih kedelai mempengaruhi masa simpan benih, yaitu berdasarkan aspek fisiologi dan biokimia. Menjawab perbedaan uji dalam metode pengusangan cepat secara kimia yang dilakukan maka, dapat dibuktikan bahwa pada konsentrasi etanol 9\% dan lama deraan 18 jam pada benih buncis belum menghasilkan penurunan viabilit, sehingga penelitian pengusangan cepat bersifat kondisional.

\section{KESIMPULAN}

Berdasarkan penelitian yang telah dilakukan disimpulkan bahwa konsentrasi etanol 9\% mampu menurunkan viabilitas benih buncis yang ditunjukkan oleh menurunnya kecambah normal total, bobot kering kecambah normal, dan meningkatkan benih mati. Lama deraan 18 jam dapat menurunkan viabilitas ditunjukkan oleh variabel kecambah normal kuat. Kombinasi antara konsentrasi etanol 9\% dan lama deraan 18 jam menghasilkan nilai viabilitas yang masih bervariasi.

\section{DAFTAR PUSTAKA}

Agustin, H. 2010. Hubungan Antara Kandungan Antosianin dengan Ketahan Benih Terhadap Pengusangan Cepat Beberapa Varietas Kedelai. Skripsi. Institut Pertanian Bogor. Bogor.

Angelo, A.J.S. \& R. L. Ory. 1983. Lipid degradation during seed deterioration. Phytopthology 73(2):315-317.

Aryati, V. 2011. Metode pengusangan cepat terkontrol untuk mengidentifikasi secara dini Genotipe Padi Gogo (Oryza sativa L.) Toleran Kekeringan. Skripsi. Institut Pertanian Bogor.

Badan Pusat Statistik. 2012. Data Produksi Buncis Tahun 1997-2010. http://www.bps.go.id/ tab_sub/view.php?tabel=1\&daftar $=1 \&$ id_subyek=55.html. 6 Maret 2012.
Buckley, W.T. \& J. Huang. 2011. An ethanol-based seed vigour assay for canola. J. Seed Sci. \& Technol. 39:510 - 526.

Kartasapoetra, A. G. 1992. Teknologi Benih. PT Rineka Cipta. Jakarta.

Miyoshi, K. and T. Sato. 1997. The efects of ethanol on the germination of seeds of japonica and indica rice (Oryza sativa L.) under anaerobic and aerobic conditions. J. Ann. Bot. 79: $391-395$.

Mugnisjah, W. Q. dan A. Setiawan. 1990. Pengantar Produksi Benih. PT Raja Grafindo Persada. Jakarta.

Pian, Z. A. 1981. Pengaruh Uap Etil Alkohol Terhadap Viabilitas Benih Jagung (Zea mays L.) dan Pemanfaatannya Untuk Menduga Daya Simpan. Disertasi. Institut Pertanian Bogor. Bogor.

Pramono, E. 2009. Daya Simpan Dugaan 90\% (DSD90) dari Intensitas Pengusangan Cepat Kimiawi dengan Uap Etanol (IPCKU) pada Benih Kacang Tanah (Arahis hypogea L.). Hasil Penelitian dan Pengabdian kepada Masyarakat. Unila.

Rubatzky, E. V. \& M. Yamaguchi. 1998. Sayuran Dunia 2, Prinsip, Produksi, dan Gizi. ITB. Bandung. (Terjemahan).

Sadjad, S. 1993. Dari Benih Kepada Benih. PT Gramedia Widiasarana Indonesia. Jakarta.

Tatipata, A., P. Yudono, A. Purwantoro, W. Mangoendidjojo. 2004. Kajian aspek fisiologi dan biokimia deteriorasi benih kedelai dalam penyimpanan. J. Ilmu Pertanian. XI (2):76-87.

Wafiroh, S. 2010. Pengujian Vigor Benih Menggunakan Metode Pengusangan Cepat Terkontrol dan Korelasinya Terhadap Daya Tumbuh dan Vigor Bibit Wijen. Makalah Seminar Departemen Agronomi dan Hortikultura, Fakultas Pertanian Institut Pertanian Bogor. Bogor.

Zanzibar, M. \& N. Herdiana. 2007. Pengaruh perlakuan pengusangan dengan uap etanol terhadap penurunan kualitas fisiologi benih akor, merbau dan mindi. J. Penelitian Hutan Tanaman. (4): 069-118. 